\title{
PEMANFAATAN KESENIAN SAKECO ETNIS SAMAWA SEBAGAI MATERI PEMBELAJARAN SASTRA DI SMP
}

\author{
Sukiman \\ ukitarano@gmail.com \\ Program Studi Pendidikan Bahasa Indonesia \\ Universitas Billfath Lamongan, Indonesia
}

\begin{abstract}
Abstrak
Penulisan artikel ini bertujuan untuk memaparkan pemanfaatan sakeco etnis Samawa sebagai sumber materi pembelajaran sastra di SMP. Sakeco dapat dimanfaatkan sebagai sumber belajar sastra khususnya di SMP. Kearifan lokal sebagai kekayaan nusantara dapat digunakan untuk sumber belajar di sekolah. Pemanfaatan sumber belajar yang dekat dengan siswa akan membantu guru mencapai tujuan pembelajaran. Salah satu bentuk kearifan lokal masyarakat Sumbawa adalah sakeco. Sakeco merupakan bentuk penyampaian puisi lawas yang paling banyak digemari oleh masyarakat Sumbawa.
\end{abstract}

Kata Kunci; sakeco, pembelajaran, sastra

\begin{abstract}
Writing this article aims to describe the use of Samawa sakeco ethnic as a source of literary learning materials in junior high. Sakeco can be used as a source of literature learning especially in SMP. Local wisdom as a wealth of archipelago can be used for learning resources in schools. The use of learning resources close to the students will help teachers achieve learning objectives. One form of local wisdom in Sumbawa is sakeco. Sakeco is a form of submission of old poetry most popular by the people of Sumbawa.
\end{abstract}

Keywords; sakeco, learning, literature

\section{PENDAHULUAN}

Indonesia merupakan negara yang kaya akan budayanya. Setiap daerah di Indonesia memiliki ragam budaya yang berbeda-beda. Keragaman budaya tersebut patut disyukuri sebagai suatu kekayaan yang perlu untuk dilestarikan dan dipertahankan. Setiap kebudayaan memiliki cara hidup sendiri, terutama dalam melakukan tindakan-tindakan sosial bagi masyarakat pemiliknya. Kenyataan yang tidak dapat dipungkiri adalah bahwa budaya ada dari hasil karya cipta manusia dari zaman nenek moyang yang telah ada dan tumbuh serta diwariskan kepada generasi penerus secara turun temurun.

Salah satu kekayaan budaya Indonesia adalah memiliki berbagai macam bahasa. Antara bahasa dan budaya seperti dua sisi mata uang yang tidak dapat dipisahkan karena bahasa merupakan salah satu fenomena budaya. Bahasa dikatakan sebagai ruh dari suatu kebudayaan karena dengan bahasa dapat mengenal dan mempelajari budaya yang ada.

Di sisi lain, bahasa merupakan alat komunikasi antar anggota masyarakat. Menurut Keraf (2001:1) bahasa adalah alat komunikasi antar anggota masyarakat berupa simbol bunyi yang dihasilkan oleh alat ucap manusia. 
Komunikasi melalui bahasa memungkinkan setiap orang untuk dapat menyesuaikan diri dengan lingkungan sosial. Komunikasi tersebut sehingga dapat memungkinkan setiap orang untuk mempelajari kebiasaan, adat istiadat, kebudayaan serta latar belakang masing-masing.

Setiap kebudayaan dari suatu daerah dapat menambah eratnya ikatan rasa solidaritas dari masyarakat yang bersangkutan. Menurut Manuaba (1999) budaya daerah merupakan kekayaan bangsa yang perlu diperhatikan dan ditangani secara serius, terutama dalam memasuki otonomi daerah dan era globalisasi. Pada era globalisasi ini tidak menutup kemungkinan budaya daerah akan terkikis oleh masuknya budaya luar.

Menurut Bascom (dalam Danandjaja 1997:19) budaya daerah memiliki empat peranan yaitu: (1) sebagai sistem proyeksi, yakni pencerminan anganangan suatu kolektif; (2) sebagai pengesahan pranata-pranata dan lembagalembaga kebudayaan; (3) sebagai alat pendidikan anak (pedagogical device), dan (4) sebagai alat kontrol agar norma-norma masyarakat akan selalu dipatuhi anggota kolektifnya. Dengan demikian, budaya daerah menampilkan dirinya dalam konfigurasinya yang sangat pluralistik.

Dalam konsep pluralisme, keanekaragaman merupakan kekayaan yang patut dilestarikan dan dikembangkan secara kondusif. Pluralisme juga mengakui bahwa realitas itu tidak "tunggal", sehingga keanekaragaman budaya Indonesia tidak perlu disatukan. Dalam pengertian, pengembangan berbagai budaya itu tetap didasarkan kepada prinsip pluralistik.

Setiap kebudayaan pada suatu daerah mempunyai tradisi tersendiri sehingga tidak dapat disamakan dengan kebudayaan di daerah lain. Sebagai contoh, di NTB terdapat banyak suku, di antaranya suku Sasak di Lombok, suku Samawa di Sumbawa, dan suku Mbojo di Bima. Ketiga daerah tersebut memiliki kebudayaan yang berbeda-beda walaupun berada pada satu provinsi yang sama. Perbedaan tersebut dapat dilihat mulai dari pakaian adat, adat perkawinan, makanan khas, kesenian, maupun perilaku dalam kehidupan sehari-hari. Hal itu menandakan bahwa keanekaragaman kebudayaan masingmasing daerah di Indonesia memiliki ciri khas yang berbeda.

Salah satu suku yang ada di Indonesia adalah Suku Samawa. Suku Samawa disebut dengan tau Samawa. Tau Samawa dalam berkomunikasi menggunakan basa Samawa. Basa Samawa salah satu kebudayaan masyarakat Sumbawa. Basa Samawa digunakan dalam berbagai kegiatan, baik itu komunikasi lisan maupun tulis, bahkan dalam penyampaian sastra pun menggunakan basa Samawa.

Sumbawa memiliki tradisi lisan yang sampai saat ini masih dipertahankan walaupun sudah mulai terkikis oleh perkembangan zaman. Tradisi lisan merupakan salah satu kearifan lokal yang tersimpan dalam karya-karya lokal, baik lisan maupun tertulis, dapat dikatakan bahwa tradisi lisan menjadi cermin dari masyarakat pemiliknya, sehingga mempelajari tradisi lisan, mulai dari 
mantra, pantun, peribahasa, hingga cerita rakyat akan sangat membantu memahami pola pikir atau berbagai kejadian dalam kehidupan masyarakat.

Tradisi lisan biasanya dibawakan dalam berbagai kegiatan adat atau acaraacara resmi. Salah satu tradisi lisan etnis Samawa ialah sakeco. Sakeco merupakan tradisi lisan yang ditembangkan sebagai bentuk ungkapan rasa cinta, sedih, kritik, dan nasihat. Sakeco disampaikan dengan menggunakan temung atau irama. Kesenian sakeco melibatkan dua pemain dan penutur yang sekaligus bertugas untuk memukul rebana sebagai musik pengiring, yang ditabuhkan saat penutur selesai menyampaikan satu bait cerita kemudian dilanjutkan ke bait berikutnya.

Kesenian sakeco tumbuh dan berkembang di dua kabupaten, yaitu Kabupaten Sumbawa dan Kabupaten Sumbawa Barat. Pembawaan sakeco biasanya mengunakan puisi lawas. Lawas merupakan karya sastra lisan Sumbawa berupa syair yang diwariskan secara turun temurun. Lawas-lawas yang dilantunkan dalam seni tradisi lisan sakeco berisi tentang cinta kasih muda-mudi, nasihat agama (akhirat), kepatriotan, perjuangan yang penuh heroik di masa lalu, politik, perkawinan, dan nilai gotong royong yang berasaskan kekeluargaan (Saleh, 2007).

Pertunjukan tradisi lisan sakeco sampai saat ini masih tetap bertahan dalam masyarakat pemiliknya. Bagi orang Sumbawa seni ini digunakan untuk memeriahkan upacara adat ramai mesaq, sunatan (khitanan), dan tokal basai. Sakeco merupakan kearifan lokal yang perlu untuk dipertahankan di tengah kemajuan teknologi saat ini.

Kearifan lokal terbentuk sebagai keunggulan budaya daerah setempat maupun letak geografis dari suatu daerah. Keaarifan lokal merupakan produk budaya masa lalu yang patut secara terus-menerus dijadikan pegangan hidup. Meskipun bernilai lokal tetapi nilai yang terkandung di dalamnya dianggap sangat universal.Kearifan lokal (local wisdom) merupakan pandangan hidup, ilmu pengetahuan, dan berbagai strategi kehidupan yang berwujud aktivitas yang dilakukan oleh masyarakat setempat untuk menjawab berbagai masalah dalam pemenuhan kebutuhan mereka (Wagiran, 2011:1).

Keberadaan masyarakat sebagai sumber nilai-nilai lokal tradisional dapat dimanfaatkan sebagai sumber belajar atau materi ajar. Nilai, norma, kebiasaan adat/tradisi, dan budaya tertentu telah menjadi keseharian masyarakat merupakan hal yang perlu diketahui dan dipelajari oleh siswa (Tilaar, 2002: 93). Implikasinya, kurikulum tidak boleh bersifat formal semata, tetapi terbuka terhadap berbagai permasalahan yang terjadi dalam masyarakat. Budaya di lingkungan unit pendidikan adalah sumber belajar dan objek studi yang harus dijadikan bagian dari kegiatan belajar siswa. Kurikulum berperan sebagai media dalam mengembangkan kebudayaan daerah dan kebudayaan nasional. 
Pengembangan materi pembelajaran harus didasarkan pada kurikulum yang berlaku. Guru dalam mengembangkan materi pembelajaran di kelas dapat memanfaatkan kearifan lokal sebagai bentuk kedekatan siswa dengan budaya daerahnya. Unsur kedekatan tersebut dapat dijadikan sebagai salah satu materi pembelajaran. Kurikulum 2013 Sekolah Menengah Pertama, khususnya kelas VII, memberikan peluang kepada kebudayaan daerah sebagai materi pembelajaran, yaitu pada kompetensi 3.9, 4.9, 3.10, dan 4.10. Keempat kompetensi dasar tersebut membahas tentang teks puisi rakyat.

Sakeco sebagai salah satu bentuk penyampaian puisi rakyat Sumbawa dapat dijadikan sebagai sumber materi pembelajaran sastra, khususnya mengungkapkan gagasan dalam bentuk puisi rakyat, baik secara lisan atau tulis. Sakeco dapat dijadikan materi pembelajaran dengan melihat bentuk dan makna di balik kegiatan sakeco. Oleh karena itu, berdasarkan paparan di atas, maka tujuan dari penulisan artikel ini adalah untuk memapaparkan pemanfaatan kesenian sakeco etnis Samawa sebagai sumber materi pembelajaran sastra di SMP. Pembelajaran sastra dikhususkan pada kompetensi dasar 3.9, 4.9, 3.10, dan 4.10 pada materi teks puisi rakyat di kelas VII.

\section{HASIL DAN PEMBAHASAN}

\section{Kearifan Lokal Sumbawa}

Kearifan lokal masyarakat Sumbawa terdiri atas berbagai macam, yaitu (1) tau Samawa, (2) basa Samawa, dan (3) lawas (karya sastra Samawa). Kearifan lokal tersebut dapat dijelaskan secara lebih rinci. Penjelasan tersebut adalah sebagai berikut.

Pertama, tau Samawa merupakan sebutan untuk masyarakat Suku Sumbawa. Secara geografis letak kehidupan Tau Samawa berada di Kabupaten Sumbawa dan Sumbawa Barat. Suku Sumbawa yang terus berkembang sampai saat ini merupakan campuran antara keturunan etnik-etnik pendatang atau imigran dari pulau-pulau lain yang telah lama menetap dan beradaptasi dengan lingkungan baru.

Etnik-etnik pendatang yang telah berbaur dengan kelompok etnik pendatang yang lebih dahulu mendiami bekas wilayah Kesultanan Sumbawa sehingga melahirkan kesadaran akan identitas budaya sendiri yang dicirikan dengan kehadiran basa Samawa sebagai bahasa pertama antaretnik yang mendiami sebagian wilayah Sumbawa dan Sumbawa Barat.

Kedua, basa Samawa merupakan bahasa yang digunakan sebagai alat komunikasi dalam kehidupan sehari-hari oleh masyarakat Samawa. Basa Samawa pecah ke dalam empat dialek, yang pada awalnya terpecah ke dalam dua dialek, yaitu pradialek Taliwang-Jereweh-Tongo dan dialek Sumbawa Besar atau cikal bakalnya disebut dialek Seran. Kemudian variasi ini berkembang 
seiring berjalannya waktu sehingga memasuki fase historis, pradialek TaliwangJereweh-Tongo pecah lagi menjadi tiga dialek yang berdiri sendiri.

Basa Samawa saat ini mengenal beberapa variasi dialek berdasarkan daerah penyebarannya, di antaranya dialek Samawa, Baturotok atau Batulante, dan dialek-dialek yang dipakai di daerah pegunungan Ropang seperti Labangkar dan Lawen. Selain itu, terdapat dialek Taliwang, Jereweh, dan dialek Tongo. Interaksi sosial yang dilakukan oleh masyarakat Sumbawa menuntut hadirnya bahasa yang mampu menjembatani segala kepentingan kelompok masyarakat.

Sebagai bahasa yang dominan dipakai oleh kelompok sosial di Sumbawa, maka basa Samawa tidak hanya digunakan sebagai alat komunikasi saja. Akan tetapi, basa Samawa digunakan sebagai media untuk memperlancar kebudayaan daerah yang didukung oleh sebagian besar pemakainya. Basa Samawa juga dipakai sebagai bahasa percakapan sehari-hari dalam kalangan elit politik, sosial, dan ekonomi, akibatnya basa Samawa berkembang dengan mendapat kata-kata serapan dari bahasa asal etnik para penuturnya, yakni etnik Jawa, Madura, Bali, Sasak, Bima, Sulawesi (Bugis, Makassar, Mandar), Sumatera (Padang dan Palembang), Kalimantan (Banjarmasin), Cina (Tolkin dan Tartar) serta Arab, bahkan pada masa penjajahan basa Samawajuga menyerap kosakata asing yang berasal dari Portugis, Belanda, dan Jepang sehingga basa Samawa kini telah diterima sebagai bahasa yang menunjukkan tingkat kemapanan yang relatif tinggi dalam pembahasan bahasa-bahasa daerah. Beberapa catatan sejarah menunjukkan bahwa nama Sumbawa sudah dikenal dalam berita Cina tahun 1225 dari Chau-Ju-Kua yang menulis Chu-FanChi, yang menyebut nama Sumbawa sebagai daerah taklukan kerajaan Kediri (Jawa) (Suyasa, 2009:2).

Selain sebagai media untuk memperlancar kebudaya, bahasa Sumbawa juga digunakan sebagai sarana pengungkapkan perasaan para sastrawan. Karya sastra sebagai sebuah proses kreativitas merupakan kritalisasi dari segala segi kehidupan. Karya sastra Sumbawa kebanyakan mengenggam amanat berupa nasihat yang bertolak pada ajaran pendidikan dan keimanan yang ditopang kuat oleh adat istiadat, seperti yang tertuang dalam bentuk lawas (puisi rakyat), ama (pribahasa), panan (teka-teki), dan tuter (dongeng) yang sangat kental dengan pesan moralitas, agama, dan etika pergaulan hidup.

Ketiga, Lawas merupakan akar atau induk dari segala bentuk kesenian dan tradisi Sumbawa, baik seni musik, tari, maupun adat-istiadat yang tumbuh dan berkembang di tengah masyarakat seperti tampak dalam sekeco, tari mata rame, permainan rakyat barapan kebo dan barapan ayam, serta tradisi daur kehidupan semisal nyorong dan barodak. Dalam segala aktivitas dan kegiatan masyarakat Sumbawa, lawas selalu dijadikan sebagai media pengisi acara. Namun, seiring berkembangnya zaman serta diiringi oleh kemajuan teknologi, 
maka lawas mulai tersingkirkan oleh musik-musik modern sebagai penganti pada saat kegiatan adat.

\section{Sakeco Etnis Samawa}

Lawas sebagai puisi lisan tradisonal masyarakat Sumbawa dapat dinikmati dalam berbagai bentuk pertunjukkan. Lawas dipertunjukkan dalam dua bentuk, yaitu di panggung dan pada saat orang bekerja di sawah, ladang, gotong royong, mengasuh anak, saat upacara adat, saat karapan kerbau, barampok sebagai sebuah tradisi (Al-Qadri, 2010). Lawas yang dilantunkan pada saat beraktivitas bertujuan untuk menghilangkan rasa sepi, bosan, dan sebagai hiburan. Kehadiran lawas bagi masyarakat Sumbawa pada awalnya berperan sebagai media ekspresi batin manusia dan perekam peristiwa yang terjadi di seputarnya. Apa yang tampak atau yang dipikirkan oleh masyarakat Sumbawa tempo dulu biasanya akan disampaikan melalui lawas.

Lawas sebagai media penyalur ekspresi batin masyarakat dibawakan dalam berbagai bentuk. Salah satu bentuk penyampaian lawas yang digemari oleh masyarakat Sumbawa adalah sakeco. Sakeco merupakan bentuk penyampaian lawas yang paling digemari oleh masyarakat Samawa. Sakeco digemari oleh masyarakat Sumbawa karena bentuk penyampaian lawas lewat sakeco yang sangat komunikatif dan lawas yang disampaikannya dari berbagai jenis dengan irama atau temung yang bervariatif (Suyasa, 2010).

Sakeco sebagai seni penyampaian lawas menggunakan rebana sebagai pengiringnya. Penyampaian sakeco selalu disesuaikan dengan irama temung. Temung atau irama sakeco menentukan keindahan penyampaiannya. Rabana yang digunakan dalam menyampaikan lawas lewat sakeco adalah rabana ode (kecil). Rabana dimainkan dengan cara dipukul serta mengikuti alunan lawas yang disampaikan. Penyampaian sakeco biasanya dilakukan oleh dua orang, baik itu secara berpasangan antara laki dan perempuan atau perempuan dengan perempuan. Lawas yang disampaikan disesuaikan dengan situasi di mana sakeco itu dibawakan.

Sakeco sebagai salah satu bentuk kesenian masyarakat Samawa yang menggunakan puisi lawas untuk menyampaikan pesan kepada pendengar memiliki bentuk yang beragam seperti: pertama, sakeco yang berbentuk narasi merupakan puisi yang menceritakan perjuangan atau cerita lingkungan kerajaan dan sejarah terjadinya sebuah daerah. Kedua, sakeco yang berbentuk ajakan atau nasihat merupakan sakeco yang menggunakan bahasa kiasan atau bahasa yang multiinterpretatif untuk menyampaikan pesan kepada pendengar. Penyampaian kedua bentuk sakeco tersebut selalu menggunakan lawas sebagai penyampaian pesannya. Lawas yang digunakan biasanya berupa septina, stanza (oktav), kuartrin, terzina, dan distikon. Kelima bentuk lawas tersebut dibawakan pada bentuk sakeco yang bersifat nasihat. 
Pemanfaatan Kesenian Sakeco Etnis Samawa

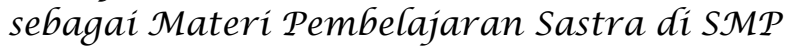

\section{Pemanfaatan Kesenian Sakeco Etnis Samawa dalam Pembelajaran Sastra di SMP}

Pembelajaran sastra di sekolah, terutama yang terkait dengan cerita rakyat dan puisi rakyat, mendapatkan tempat yang proporsional di dalam Kurikulum 2013. Penanaman nilai-nilai kebudayaan Indonesia yang beragam juga dapat dilakukan dengan memberdayakan pembelajaran sastra lisan yang sumbernya berasal dari berbagai daerah di Nusantara. Sumber belajar sastra yang dapat digunakan di sekolah disesuaikan dengan karakteristik lingkungan tempat tinggal siswa serta konteks kedaerahan.

Keberadaan sastra daerah akan selalu mengalami perubahan sesuai dengan dinamika masyarakat pemiliknya. Perubahan tersebut meliputi pola dan cara pandang tentang kehidupan, serta terbatasnya kemampuan masyarakat dalam menginterpretasikan warisan budaya yang diterimanya. Kemampuan yang terbatas pada masyarakat dalam mewarisi kekayaan budaya yang berupa sastra lisan serta adanya arus pengaruh dari luar akan menyebabkan hilangnya beberapa bentuk sastra serta terjadinya pergeseran makna, fungsi, dan timbulnya variasi bentuk. Teeuw (2015:330) mengatakan bahwa sastra lisan pun sering mempunyai dinamika intrinsik yang kuat sekali atau pun berubah akibat pengaruh asing (tulis atau lisan).

Sastra lisan di Indonesia sangat memungkinkan terjadinya perubahan. Hal ini merupakan akibat pergesekan antarbudaya yang sangat tinggi walaupun pada beberapa ragam dasar masih bisa bertahan lama. Disadari atau tidak oleh masyarakat pemiliknya, ternyata dalam perkembangannya sastra lisan telah melahirkan berbagai konfigurasi sebagai gambaran keterbukaan masyarakat dalam menerima budaya orang lain yang dianggap masih sejalan. Salah satu upaya untuk mempertahankan sastra lisan agar tetap bertahan dengan menjadikan sastra lisan sebagai topik pembicaraan di sekolah (Amir, 2013:14).

Terkait dengan pembelajaran sastra lisan sebagai kearifan lokal di SMP, Sutarno (2008: 7-8) mengatakan ada empat macam pembelajaran berbasis budaya. Pertama, belajar tentang budaya, yaitu menempatkan budaya sebagai bidang ilmu. Budaya dipelajari dalam program studi khusus, tentang budaya dan untuk budaya. Dalam hal ini, budaya tidak terintegrasi dengan bidang ilmu. Kedua, belajar dengan budaya, terjadi pada saat budaya diperkenalkan kepada siswa sebagai cara atau metode untuk mempelajari pokok bahasan tertentu. Belajar dengan budaya meliputi pemanfaatan beragam untuk perwujudan budaya. Dalam belajar dengan budaya, budaya dan perwujudannya menjadi media pembelajaran dalam proses belajar, menjadi konteks dari contoh-contoh tentang konsep atau prinsip dalam suatu mata pelajaran, serta menjadi konteks penerapan prinsip atau prosedur dalam suatu mata pelajaran. Ketiga, belajar melalui budaya, merupakan strategi yang memberikan kesempatan siswa untuk 
menunjukkan pencapaian pemahaman atau makna yang diciptakannya dalam suatu mata pelajaran melalui ragam perwujudan budaya. Keempat, belajar berbudaya, merupakan bentuk mengejawantahkan budaya itu dalam perilaku nyata sehari-hari siswa.

Sutarno (2008: 7-10) mengungkapkan ada tiga macam model pembelajaran berbasis budaya, yaitu: (1) model pembelajaran berbasis budaya melalui permainan tradisional dan lagu-lagu daerah, (2) model pembelajaran berbasis budaya melaui cerita rakyat, dan (3) model pembelajaran berbasis budaya melalui penggunaan alat-alat tradisional. Keragaman budaya dapat dijadikan sebagai sumber belajar, khususnya pembelajaran sastra. Memasukkan sastra daerah atau budaya daerah ke dalam materi pembelajaran di kelas dapat membantu untuk melestarikan eksistensi sastra daerah.

Nilai-nilai yang terkandung dalam sastra daerah juga perlu untuk ditumbuhkan kepada siswa, melihat perkembangan teknologi yang semakin pesat. Perkembangan itu tentu membawa dampak negatif bagi siswa, baik yang menyangkut nilai-nilai moral ataupun perbuatan yang tidak terpuji. Mengatasi masalah tersebut dapat dilakukan dengan nilai-nilai luhur yang terkandung dalam sastra daerah. Guru sebagai pemegang kendali dalam pembelajaran di kelas, dapat memanfaatkan segala sumber belajar yang terdekat dengan lingkungan siswa.

Salah satu bentuk kebudayaan masyarakat Sumbawa yang dapat dijadikan materi pembelajaran sastra adalah kesenian sakeco. Kesenian sakeco merupakan bentuk penyampaian puisi rakyat Sumbawa (lawas). Sakeco disampaikan secara aktraktif oleh dua orang. Penyampaian puisi lawas lewat sakeco paling banyak digemari oleh masyarakat Sumbawa.

Sakeco dapat dijadikan materi pembelajaran sastra di SMP sesuai dengan isi silabus pelajaran Bahasa dan Sastra Indonesis kelas VII. Pada silabus pelajaran bahasa dan Sastra Indonesia kelas VII, terdapat kompetensi dasar yang memberikan peluang untuk kesenian daerah dijadikan materi pembelajaran. Kompetensi tersebut membahas tentang teks puisi rakyat, yaitu pantun, syair, dan bentuk teks puisi rakyat daerah setempat. Oleh karena itu, kesenian sakeco yang menggunakan puisi lawas sebagai isi dalam penyampaiannya dapat dijadikan materi pembelajaran.

Pemanfaatan sakeco dapat diimplementasikan dengan cara mengapresiasikan dan menulis puisi lawas Sumbawa. Selain itu, siswa juga dapat mengungkapkan gagasan dalam bentuk puisi lawas Sumbawa yang nantinya akan dibawakan dalam bentuk sakeco. Ada beberapa tahapan yang dapat dilakukan dalam pemanfataan kesenian sakeco sebagai materi pembelajaran sastra, yaitu (1) siswa diarahkan untuk menulis puisi lawas Sumbawa terlebih dahulu, (2) puisi lawas Sumbawa yang dibuat oleh siswa disunting terlebih dahulu untuk melihat kesesuaian strukturnya, (3) setelah 
tahapan penyuntingan dilakukan, siswa dapat berlatih secara berpasangan untuk menyampaikan puisi lawas Sumbawa dalam bentuk sakeco, dan (4) siswa yang sudah siap, akan menampilkan kesenian sakeco sesuai dengan isi puisi yang sudah dibuatnya di depan kelas.

\section{SIMPULAN}

Kearifan lokal dapat dijadikan sebagai sumber belajar di dalam kelas. Salah satu kearifan lokal masyarakat Sumbawa adalah kesenian sakeco. Sakeco sebagai bentuk penyampaian puisi lawas dapat dijadikan materi pembelajaran sastra. Sastra daerah sebagai salah satu bentuk warisan nusantara memiliki unsur kedekatan dengan lingkungan siswa. Sastra daerah memiliki nilai-nilai sosial yang patut untuk ditumbuhkan kepada siswa.

Pemanfaatan kesenian sakeco masyarakat Sumbawa sebagai materi pembelajaran sastra dapat dimplementasikan pada kompetensi dasar 3.9, 3.10, 4.9, dan 4.10 tentang teks puisi rakyat. Pada kompetensi dasar tersebut memberikan peluang kepada sastra daerah untuk dijadikan materi pembelajaran di kelas. Pemanfaatan sastra daerah sebagai materi pembelajaran bertujuan agar siswa mampu untuk mengenal khazana daerahnya. Selain itu, siswa juga dapat mengenal, memahami, dan mengapresiasikan sastra daerahnya.

\section{DAFTAR PUSTAKA}

Al Musafiri, M. Rizqon, Sugeng Utaya, I Koman AStina. 2016. Intengrasi NilaiNilai Kearifan Lokal Suku Using dalam Pendidikan Karakter Sekolah Menengah Atas.(Online). (http://ap.fip.um.ac.id/wpcontent/uploads/2016/03/19-M.-Rizqon-Al-Musafiri-Sugeng-Utaya-IKomang-Astina.pdf.2016, diakses 29 Oktober 2016).

Al-Qadri, Fathi. 2010. Lawas dalam Kehidupan Masyarakat Sumbawa. (Online). (http://kemassamawimultiproduction.blogspot.com/2009/05/la was-dalam-kehidupan-masyarakat.html, diakses 20 Oktober 2016).

Amir, Adreyetti. 2013. Sastra Lisan Indonesia. Yogyakarta: Andi Offset Saleh, Muhammad. 2016. Sastra lisan (lawas) etnis samawa dan muatan nilai keagamaannya. Jurnal Penelitian Keislaman Vol 4, No. 1, hal 120.

Danandjaja, James. 1997. Folklor Indonesia: IlmuGosif, Dongeng, dan Lain-lain. Jakarta: Pustaka Utama Grafiti.

Holilah, Mina. 2015. (Kearifan Ekologis Budaya Lokal Masyarakat Adat Cigugur sebagi Sumber Belajar IPS). JPIS, Jurnal Pendidikan Ilmu Sosial, Vol. 24, No. 2, Edisi Desember 2015.2 (Online). (http://ejournal.upi.edu/index.php/jpis/article/download/1453/1001, diakses 29 Oktober 2016).

Keraf, Gorys. 2001. Komposisi. Ende Flores: Nusa Indah. 
Sukiman

Manuaba, Putera. 1999. Budaya Daerah dan Jati Diri Bangsa: Pemberdayaan Cerita Rakyat dalam Memasuki Otonomi Daerah dan Globalisasi. Jurnal Masyarakat, Kebudayaan dan Politik, Th XII, No 4, Oktober 1999, 57-66. (Online). (http://journal.unair.ac.id/download-fullpapers-06Manuaba.pdf, diakses 20 Oktober 2016).

Sutarno. 2008. Pendidikan Multikultural. Jakarta: Direktorat Jendral Pendidikan Tinggi Departemen Pendidikan Nasional.

Suyasa,Made.2009. WacanaSeniBalawasdalamMasyarakatSamawa. Disampaikan dalam Seminar Nasional Bahasa dan Sastra Indonesia. Mataram: Tidak diterbitkan.

Teeuw, A. 2015. Sastra dan Ilmu Sastra: Pengantar Teori Sastra. Jakarta: Dunia Pustaka Jaya.

Tilaar, HAR. 2002. Pendidikan, Kebudayaan, dan Masyarakat Madani Indonesia. Bandung: Remaja Rosdakarya.

Wagiran, 2011. Pengembangan Model Pendidikan Kearifan Lokal dalam Mendukung Visi Pembangunan provinsi DaerahIstimewa Yogyakarta 2020. (online). (http://staff.uny.ac.id/sites/default/files/penelitian/Wagiran, $\% 2$ OS.Pd.,M.Pd.,\%20Dr./Pendidikan\%20kearifan\%20lokal.pdf. Diakses 29 Oktober 2016). 